\title{
1. Financial innovation and the consequences of complexity: insights from major US banking crises
}

\author{
Robert F. Bruner, Sean D. Carr and \\ Asif Mehedi
}

Complexity and instability have been persistent features of the American financial system since the earliest days of the republic. Beginning with Alexander Hamilton's Bank of the United States in 1791, the growth of the banking sector and the ever-deepening interconnections among banks and bank-like institutions have coincided with cycles of crashes, panics, financial crises, and, in some cases, depressions. One view is that the absolute complexity ${ }^{1}$ of the financial system, especially in its instruments and institutions, is itself a material source of the instability; that is, as the banking sector has grown more complex, so has its tendency toward disequilibrium and dysfunction. We suggest an alternate view that complexity by itself is not a sufficient condition to precipitate systemic vulnerability. Instead, we observe that complex financial systems may fall out of equilibrium with the introduction (or adoption) of novel financial instruments, institutions or markets - that is, financial innovations. Such innovations have the potential, we suggest, to amplify negative dynamics within complex systems and, under certain conditions, may result in significant adverse consequences.

Drawing from the growing body of literature that applies concepts from the study of complex adaptive systems to economics (for example, Arthur, 2014) and financial markets (for example, Beinhocker, 2007; Sornette, 2003), this chapter explores two interrelated features of complex financial systems that may serve as the mechanisms by which innovation can induce financial instability: tight linkages and information flows. The system-like architecture of the banking sector often creates opacity that makes it difficult for information to flow freely when trouble occurs; also, a complex system creates tight linkages whereby the trouble itself can quickly spread. 
These features are not static but dynamic, and they appear to intensify with the arrival of innovations: new, complex instruments, institutions and markets further contribute to uncertainty and exacerbate the overall fragility of the system.

This chapter is an exercise in inductive research. Drawing from narratives about six consequential American banking panics beginning in 1792, we seek to frame and embellish a hypothesis that, under certain conditions, innovation in financial instruments, institutions and markets ${ }^{2}$ amplifies complexity in the financial system, which in turn increases the propensity for financial crisis and economic distress. We call this the InnovationComplexity hypothesis. Using the foregoing theoretical lens through which to understand the impact of endogenous system complexity, we explore how financial innovations interact with that complexity over time, thereby amplifying systemic risks.

In the discussion of the recent Global Financial Crisis, the role of financial innovation features prominently. The role of innovation in the preceding financial crises, however, has been largely ignored. Through six micro-case studies, we aim to draw sharper inferences about how innovation in the US banking sector might be a common contributing factor in the occurrence, severity and duration of financial crises.

\section{THE LONG VIEW: FINANCIAL CRISES RECUR}

First, let us begin with a description of our outcome variables. A financial crisis is an episode of severe threat to the stability, safety and soundness of the financial system in the economy. A crash, or sharp decline in security prices, often precedes or coincides with a financial crisis, though many crashes have occurred without a corresponding financial crisis. A crash may also occur at the end of an asset price bubble - rapid growth in asset price over a short time - to correct overvaluation of assets. A financial crisis typically includes a panic, in which depositors and lenders frantically seek to withdraw their money from institutions and markets, though the panic may be only one episode of the longer period of instability. A financial crisis usually triggers or aggravates an economic recession, though many recessions have not featured financial crises. A financial crisis commences with some kind of economic shock and ends when financial market conditions return to normal.

Here, we focus on banking crises - the kind of financial crises where a large number of banks become unable to meet their obligations to depositors and lenders because of illiquidity or insolvency. A widespread loss of confidence among depositors and lenders and the resulting panic 
often cause or precipitate large-scale bank failures, measured either in the number of insolvent banks or in the aggregate value of insolvency. From 1814 to 1914 , the US saw 13 banking crises. Generally, those crises followed periods of robust growth and occurred in the context of a recession - although not every recession featured a banking crisis.

The founding of the US Federal Reserve in 1913 ameliorated but did not prevent banking crises thereafter. In fact, the century since has witnessed three major episodes of financial crisis: 1930-34, 1987-89 and the Global Financial Crisis commencing in 2007. In each of these periods, the number and/or dollar value of financial institutions seized by regulators far overshadowed the trickle of seizures under normal conditions. From the long view, the kinds of events that may precipitate financial crises are more notable by their absence than their appearance.

\section{THE INNOVATION-COMPLEXITY HYPOTHESIS}

Complexity has been endemic to the modern financial system since its earliest days. If we consider the evolution of the financial system over time, we observe an ever-growing number of financial institutions. Moreover, as we see in Figure 1.1, the overall scale and scope of the banking system grew steadily, punctuated by an almost regular cadence of banking panics and financial crises.

Growth in the number of components alone does not translate into greater complexity. What matters more is the increase in types of those components. For example, the founding of many of the same types of banking institutions does not necessarily make the financial system more complex. However, as the financial system evolves, many new types of institutions (and instruments and markets) may emerge. This constant evolution and change is what increases heterogeneity in the system. Our argument is that this heterogeneity, the result of a continuing gale of financial innovation, makes the financial system more fragile and vulnerable to distress.

This observation alone, however, does not explain how innovation within a complex adaptive system can trigger instability. We suggest that innovation can amplify the problems associated with two key features of complex systems: tight linkages and information flows. First, the very existence of a tightly linked complex system means that trouble can travel; the difficulties of one financial intermediary can easily extend to others (Allen and Gale, 2000). Second, the complexity of a financial system heightens the possibility of information asymmetry, where some participants are informationally disadvantaged relative to others, potentially resulting in adverse behaviours. 
(\%) daり ןед ןenuue u! әбиечว

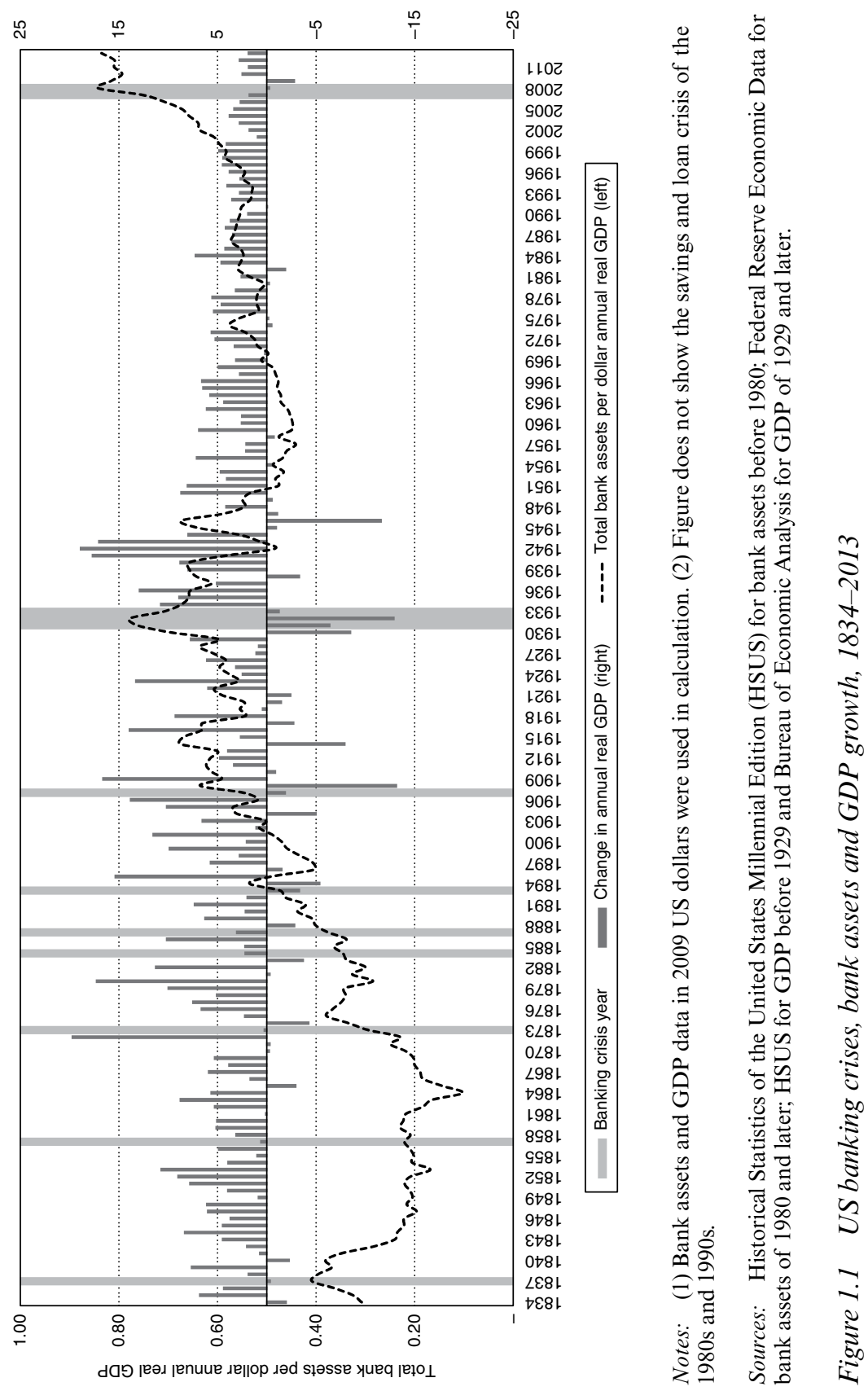


Innovations can make such a dynamic system, or a part of it, even more opaque and less easy to understand. This may happen when a new type of instrument or institution is so complex in its features and functions that its effects on counterparties, and the system as a whole, are hard to assess. The consequent information asymmetry in such a system results in heightened uncertainty. Such lack of transparency in a tightly coupled system is particularly dangerous, because, while the components are interdependent in such a system, the extent of the interdependence is not visible. Moreover, during the run-up to a crisis, it becomes difficult to contain the cascade of failures, because regulators and institutions, with restricted visibility, fail to identify the channels of the failures' propagation.

\section{LINKAGE SO THAT TROUBLE CAN TRAVEL}

Fundamental to the definition of a system is that its parts are linked and interact. Thus, it is in a household heating system (the furnace and thermostats interact in a feedback loop), the digestive system (the body's organs are interdependent and operate for the benefit of all) and the telecommunications system (a network increases in utility as connectivity with other people increases). A financial system has similar characteristics: the various intermediaries (banks, trust companies, brokerage firms) are lenders and creditors to each other by virtue of the cash transfers that they facilitate.

In any system, trouble will spread unless shock absorbers exist to stop it. Today, the safety buffers for the financial system would include the Federal Reserve, the International Monetary Fund, the Bank for International Settlements, the World Bank and central banks around the world. The key question is whether the safety buffers in existence at various periods in time are adequate to prevent the spread of potential shocks. Adequacy is defined relative to the size of the available assets and their liquidity versus the size of liabilities and the probability of the shocks, which the buffer is meant to absorb. Over time, the size and complexity of the economy may outgrow the sophistication of static financial safety buffers (Bookstaber, 2007).

An important insight from the field of system dynamics is that systems can also display surprising nonlinearities - this means that orderly systemic structures may produce unpredictable behaviour. Feedback loops, time delays and other factors affect the behaviour of entire systems. In recent years, the study of complex systems has evolved into an advanced interdisciplinary field. ${ }^{3}$ The application of concepts from system dynamics to the study of financial markets is relatively new. 
Charles Perrow (2009), a sociologist who studied some major infrastructure accidents (for example, in power systems and nuclear facilities), argued that complex and tightly coupled systems are inherently vulnerable to accidents (the 'normal accident' theory). By complexity, he denoted the possibility of unexpected interactions among system parts resulting in a local failure. Tight coupling allows the local failure to cascade throughout the system. The financial system is similar to large infrastructures in that they both share complexity and tight coupling, and so financial crisis is, if not inevitable, hard to evade.

The basis for tight coupling in the financial system is the financial contract, which is one of those fundamental inventions that changed the trajectory of society's economic progress. By its very function of transferring an asset from one party to another and simultaneously creating a promise for future payment, a financial contract tightly connects two actors within a system. Certain instruments and institutions can turn that link into a dependency, whereby one entity's survival depends on that of another. Moreover, these contracts create a chain of dependencies, making an entity in one part of the financial system dependent on another entity several degrees away in another part of the financial system.

Financial institutions are particularly tightly linked within the system by means of inter-firm transactions and deposit-taking. The financial system was international as early as the Renaissance (for example, the Fuggers and the Medici), in the sense of institutions in different countries being linked through transactions and deposits. Kindleberger and Aliber (2005) noted that over time the waves of financial crises have had a strong international dimension to them because of such linkages.

\section{PROBLEMS OF INFORMATION}

The other relevant aspect of complexity for financial systems has to do with the opacity of information. Complexity within a financial system prevents all participants in the system from being equally well informed (Caballero and Simsek, 2009). This results in information asymmetries that can prompt irrational behaviour, thereby triggering or even worsening a financial crisis (Kindleberger and Aliber, 2005). Information asymmetries may lead to the problem of adverse selection, whereby better-informed people might exploit the poorly informed.

Economists Douglas Diamond and Phillip Dybvig (1983) have suggested that bank panics are simply randomly occurring events. Bank runs occur when depositors fear that a random externality will force the bank into costly and time-consuming liquidation. To be last in line to withdraw 
deposited funds exposes the individual to the risk of loss. Therefore, a run occurs simply from the fear of random deposit withdrawals and the risk for the individual of being last in line.

Diamond and Dybvig said that a run on a bank occurs when 'depositors rush to withdraw their deposits because they expect the bank to fail. In fact, the sudden withdrawals can force the bank to liquidate many of its assets at a loss and to fail' (1983, p.401). The mismatch of liquidity between a bank's assets and liabilities - a mismatch allowed by conventional demand deposit contracts - leads to the self-fulfilling concerns of the depositors about bank failure. The run is merely one of two possible equilibria in a conventional bank. The occasional banking crisis, they suggest, is therefore both random and inevitable.

Other scholars, however, strongly contend that bank runs and ensuing panics are neither random nor inevitable, but are a consequence of the uneven distribution of information among actors within the system. Calomiris and Haber (2014), for example, have disagreed with the inevitability of bank runs, citing examples of countries where banking crises are rare (for example, Canada). In their view, the propensity of crisis in a banking system is determined by 'the way that the fundamental political institutions of a society structure the incentives of politicians, bankers, bank shareholders, depositors, debtors, and taxpayers to form coalitions in order to shape laws, policies, and regulations in their favor - often at the expense of everyone else' (Calomiris and Haber, 2014, p.4).

Thus, bank runs may result from asymmetric information: the problem of adverse selection can motivate panic selling or the withdrawal of deposits. Calomiris and Gorton (1991) suspected that runs could begin when some depositors observe negative information about the value of bank assets and withdraw their deposits. Then, other depositors follow suit, being unable to discriminate perfectly between sound and unsound banks and observing a wave of withdrawals. A run begins. In a world of unequally distributed information, some depositors will find it costly to ascertain the solvency of their banks. Thus, runs might be a rational means of monitoring the performance of banks - a crude means of forcing the banks to reveal to depositors the adequacy of their assets and reserves.

Calomiris and Gorton (1991) reasoned that if the information asymmetry theory were true, panics would result from real asset shocks that would cause a decline in the collateral values underpinning bank loans. They found that panics tended to follow sharp declines in the stock markets and that they tended to occur in the spring and autumn. They also reasoned that the resolution of a bank panic would result from the elimination of an important aspect of the information asymmetry: gaining clarity as to 
which banks were solvent or insolvent would slow down or stop the runs on solvent banks.

Empirical research gives some support to the asymmetric information theory over the random withdrawal theory, but the findings are not uniformly supportive. Studies have considered how well information asymmetry explains panics by looking at whether deposit losses predict panics, whether the yield spreads between low- and high-risk bonds peak at the panic, and whether real declines in the stock market are greater in panic years than in non-panic years - generally, these findings affirm the information asymmetry view (Mishkin, 1991; Carlson, 2005).

Taleb (2012) has argued that opacity in a financial system allows system participants to hide the consequences of their actions and thus creates perverse incentives for those participants to take undue risks. He has therefore suggested that ensuring financial system participants' 'skin in the game' through aligned incentives would be much more effective than a myriad of regulations in making a financial system less fragile. ${ }^{4}$

Drawing from these ideas, our study explores how innovation might enlarge the theory of complexity and information asymmetry. Along with regulation, innovation, which is a more spontaneous phenomenon driven by market incentives, is a source of change in the banking system. When such change adversely affects the system, vulnerability increases and a banking crisis becomes more likely.

\section{LOOKING FOR EVIDENCE: SIX MAJOR US BANKING CRISES}

In the following section, we offer six micro-histories of banking crises in the US to explore the plausibility of the Innovation-Complexity hypothesis. Here, we seek to suggest some of the ways in which innovations in financial instruments, institutions and markets may have contributed to an amplification of systemic risks during each of these periods.

\section{The Panic of 1792}

The US's first major episode of financial instability provides us with three examples of how innovations in instruments, markets and institutions may have amplified systemic complexity and contributed to a crisis. In this case, the innovations were: the issuance of restructured bonds by the US government (instruments); the creation of a trading market for US bonds (markets); and the founding of the Bank of the United States (institution).

With the close of the Revolutionary War (1787) and the replacement of 
the Articles of Confederation by the new Constitution (1789), Secretary of the Treasury Alexander Hamilton turned to modernize the financial system of the young US. In the course of 24 months, he submitted to Congress three landmark reports that contained innovative (and consequential) recommendations for reform. Among them was the creation of a more liquid and orderly market for US government debt through the establishment of a sinking fund, whereby the government could engage in open-market refunding operations (that is, borrow money to repurchase debt) when economically advantageous.

Another key recommendation was the establishment of the first Bank of the United States (BUS). This provision would create a central bank in the US that would establish a uniform national currency, assure the soundness of the currency through capital market operations and oversee the safety and soundness of the private banks in the country. A particular novelty of this plan was that the public could buy shares in BUS with gold, silver and the newly refunded US bonds.

Within a year, the restoration of public credit and the successful founding of BUS spurred a bull market in US bonds and in shares of BUS. This reflected rising confidence in Hamilton's restructuring programme and in the credit of the US government. New banks were organized and financial market liquidity grew. However, the new environment also stimulated speculative excesses.

In late 1791, William Duer and a circle of co-investors organized a pool of funds to speculate on the initial offering of a new bank in New York City and on US bonds. Duer had been an Assistant Treasurer of the US, serving under Hamilton, and was a close acquaintance. Hamilton was unaware of Duer's speculation. Borrowing from banks in New York and from BUS in Philadelphia, Duer's pool invested in bank shares and government debt, seeking to corner the market. In January and February 1792, the pool operated profitably. Inflated with his own success, Duer borrowed more heavily to take personal investment positions outside of the pool.

Hamilton sought to prick this asset bubble, an extremely delicate operation and a subject of intense debate among central bankers and their critics some 223 years later. Watching the spiralling security prices in the spring of 1792, Hamilton ordered BUS to constrict its lending, especially to speculators. Because BUS could call in credits to other financial institutions, this action had a systemic impact. In early March, the upward price momentum stalled. By 20 March, the leading series of US bonds had fallen 25 per cent in price in two weeks. Consequently, William Duer and his circle defaulted on their debts on $8 \mathrm{March}$ - the failure of this prominent group cast a pall over confidence in the economic recovery and over the stability of banks, including BUS. Investor and business failures mounted. 
Hamilton recognized that panic could unravel the financial fabric he had carefully knitted over the previous two years and commenced open-market purchases and lender-of-last-resort commitments. He engaged in active jawboning (moral suasion) with a circle of influential bond dealers to get them to act collectively with the Bank of New York in arranging bank credit on securities collateral. Because of Hamilton's month-long active intervention, the effect of the financial crisis on the real economy of the US was minimal.

Of course, the financial system of the 1790s was much simpler than today's in both the number and types of financial institutions. Nonetheless, this crisis illustrates that even a nascent financial system can exhibit the characteristics of a complex system: unpredictable and nonlinear interactions leading to emergent system-level instability. Hamilton's innovative scheme - that the price of BUS shares could be paid with US bonds created an inadvertent interdependence between the two instruments. Consequently, it was difficult to assess the risks and value of these instruments; the wild swings in securities prices in the first year of BUS evidence this difficulty.

In such an environment of unpredictable dynamics, Duer's lenders lacked an appreciation of the risks he was taking, but continued to lend to him, relying solely on his reputation. Duer's privileged knowledge of the workings of the new financial system also created information asymmetry between him and his lenders about the risks of his investments, a situation that he was initially able to exploit. All this created a chain of dependence spanning BUS, Duer and his fellow speculators, a large number of banks and individual lenders who lent to these speculators, and the depositors of those banks. These dependencies and asymmetries tested the resilience and flexibility of the nascent financial system. The Panic of 1792 suggests that even in relatively simple contexts, innovations in instruments (US government debt), institutions (BUS) and markets (trading in US bonds and BUS shares) can contribute to the creation of an asset bubble and its eventual bursting.

\section{The Panic of 1873}

The events of 1873 present more examples of how novel developments in financial instruments (asset-backed bonds), institutions (national banks) and markets (secondary trading markets for railroad bonds) may have precipitated a serious banking crisis. Again, they suggest how innovation may adversely affect a fragile, complex system.

Following the cessation of the Civil War in 1865, the US economy expanded sharply. Railroads, financed by bonds, expanded their trackage 
at a rapid pace without much regard for immediate demand. This expansion was a result of liberal inducements offered by the Federal Government in the form of land grants to the railroads. Thus, investors in railroad bonds looked to the collateral value of the granted land for comfort in the face of the risky railroad expansions. However, the value of the land depended in turn on an assumption that the presence of the railroad would stimulate the settlement of land by farmers, the establishment of towns and cities, and vigorous economic development that would assure growing railroad revenues. All of this presumed that the railroads would lay tracks to economically attractive lands. But, by definition, 'overexpansion' meant that railroads were laying tracks to marginally attractive, or even unattractive, regions. This suggested a cynical game of expansion simply to acquire land grants in order to sell bonds and get cash to lay more track. Sooner or later, bondholders would stop the music and the system would crash.

The market for railroad bonds, however, slowed down in the summer of 1873, as foreigners in particular started to shun investment in railroads. Europe endured its own financial turmoil, with the Vienna Stock Exchange crashing in May of that year following several years of overexpansion of the economies in central Europe.

Two notable financiers of railroads failed in the first half of September 1873. And on 18 September, the collapse of Jay Cooke \& Co., after a failed underwriting of Northern Pacific Railroad bonds, triggered full-blown panic. In an environment of distrust and uncertainty, the banks called in loans en masse. Numerous banking and brokerage firms failed in the following few days. The New York Stock Exchange, in an unprecedented move, closed for ten days from 20 to 30 September.

On 20 September, the New York Clearing House Association promptly and decisively set up an arrangement - the issuing of Clearing House Loan Certificates, a quasi-currency, to member banks against various securities - that essentially made the association a lender of last resort and successfully contained further cascading of bank failures in the city.

While the overinvestment in railroad construction was an important contributor to the banking crisis, one complementary cause lay in the fundamental structural vulnerability of the banking system of the day. Two innovative features of the system - interest-paying bankers' deposits and national banks - are particularly relevant in the discussion of this vulnerability.

The practice of paying interest on demand deposits started in the 1830s but accelerated after the Civil War. The interior banks, which operated in agrarian economies and thus had a seasonal liquidity cycle, held demand deposits (known as bankers' deposits or bankers' balances) with banks in the large cities, especially in New York, during the summer months. In the 
autumn, following the harvest as crops moved by rail to the coastal cities, money flowed back to the interior banks, producing a general environment of monetary stringency in the east and west. Not all banks participated in this practice, but those that did engaged in speculative investment in the form of call loans, which earned a return on the bankers' deposits.

Further incentive for the bankers' deposits came from a provision of the national banking laws that allowed interior banks to keep three-fifths of their legal reserve with the banks in 15 designated reserve cities. In turn, these banks in the reserve cities could keep half of their legal reserve with banks in New York City. This pyramid structure introduced both opacity and tight coupling in the system. The banks in the system did not have full transparency of this tiered structure of bankers' deposits and of the cascade of failures that could play out in adverse circumstances. This opacity also exacerbated information asymmetry, as interior banks had little understanding of the risks certain New York banks were taking with the deposits that came from the interior. When trouble occurred, the tight coupling of the banks across the three tiers enabled the channeling of trouble from one part of the system to another.

In 1873, seven of the 60 New York banks held 70 to 80 per cent of all bankers' deposits in the city. Because of this significant concentration, these seven banks (all of them paid interest on bankers' deposits) were, in Harvard Professor Oliver Sprague's (1910) words, 'directly responsible for the satisfactory working of the credit machinery of the country' (Sprague, 1910 , p. 15). Before the crisis, bankers' deposits had already started to flow to the interior banks to finance the purchase and transportation of a particularly plentiful harvest that autumn; those seven banks found themselves short of the required reserve. This contributed to the breakdown of the credit machinery after the collapse of Jay Cooke \& Co.

\section{The Panic of 1893}

The episode of 1893 engenders the hypothesis that innovations in national monetary policy may be sufficient to fuel a banking panic. Scholars disagree on the extent of influence of monetary policy in prompting this crisis; clearly, any crisis will have many possible causes. Yet, in this instance, the impact of policy innovations requires further attention. The innovations in question - namely, relaxation of the gold standard to include silver coinage and protectionism through high tariffs - stand as two of the root causes of this crisis.

Some historians date the onset of the crisis from two prominent bankruptcies: the Philadelphia \& Reading Railroad on 20 February 1893 and National Cordage on 5 May. The overall volume of bankruptcies in 1893 
rose 50 per cent over the year before, and liabilities tripled. The stock market crashed in early May, and over the next four months, the banking system suffered a wave of illiquidity, bank runs and more than 500 bank suspensions (Wicker, 2006). By mid-autumn, financial conditions had started to brighten, although the aftershocks of the panic lasted through 1896. These included a 26 per cent decline in GDP, two devastating strikes (Homestead and Pullman), a march on Washington, DC, by Civil War veterans demanding benefits and an increase in the money supply (Coxey's Army), and a dramatic midterm Congressional election (1894), which still stands as the biggest reversal of a Congressional majority in US history.

Two scholars, Oliver Sprague (1910) and Elmus Wicker (2006), conclude that the Panic of 1893 sprang from the flaws of the US financial system of the late nineteenth century: the inelasticity of the money supply; the difficulties by which bankers took collective action to fight runs; and the absence of a lender of last resort. On the other hand, the context of 1893 suggests that there may be more to the explanation.

Twenty years earlier, Congress had stopped the coinage of silver, bringing the US back to a simple gold standard. During the ensuing two decades, silver production boomed, owing to the opening of numerous mines in the western US. Simultaneously, agricultural prices fell, which prompted calls for inflationary monetary policy - specifically, the coinage of silver. In 1890, Congress passed the Sherman Silver Purchase Act, which required the monthly purchase of 4.5 million ounces of silver, payable in paper money. This legislation created a silver-backed currency that was 'as good as gold'. Since paper currency could now be redeemed in gold, the act set in motion an arbitrage against the US government any time that the market prices for silver and gold deviated from the 16:1 ratio fixed by the Bland-Allison Act of 1873 . Thus, a slow but unmistakable run on the US Treasury's gold reserves ensued.

At the same time, Congress passed the McKinley Tariff Act, which pivoted government policy sharply towards the protection of domestic producers. The consequence of this was a decline in imports, fiscal strain on the US government and faster depletion of gold reserves. Tariff revenues to the US government were a vital source of gold with which to back the currency. Finally, in 1890, the default by Argentina on loans from foreign lenders and the subsequent failure of Baring Brothers prompted a general 'flight to safety' by European investors: they sold their holdings of American bonds in the US, demanded payment in gold and shipped the gold back to Europe.

In short, the worsening monetary conditions prompted the onset of a recession in early 1893, a precursor to crisis. As the US Treasury's gold reserves dwindled, investors feared the government's ability to honour 
its obligations in gold. On 21 April, the government's gold reserves fell below the $\$ 100$ million minimum; Treasury Secretary Carlisle said that the Treasury would continue gold payments, 'as long as it has gold lawfully available for the purpose'. Investors supposed that Carlisle might begin to redeem gold obligations with silver. Within ten days, the stock market felt its worst decline since 1884. On 1 May, National Cordage declared bankruptcy, which its president attributed to an inability to secure credit.

Several scholars have suggested that the policy innovations (silver and protectionism) were important drivers of the Panic of 1893. A.D. Noyes (1909) wrote that, 'although the financial fright of 1893 arose from fear of depreciation of the legal tenders, the first act of frightened bank depositors was to withdraw these very legal tenders from their banks' (Noyes, 1909, p. 190). Friedman and Schwartz (1963) acknowledge both causes:

[T]wo sets of forces were responsible for the two different drains: distrust of the Treasury's ability to maintain silver at parity with gold caused the external drain; distrust of the solvency of banks, particularly western institutions, caused the internal drain. The link between them was the effect on the solvency of banks of the additional deflation that was produced by a decline in capital in flow arising out of doubt about the maintenance of the gold standard. (1963, p. 109)

Even Sprague's (1910) account agrees that the silver issue did play a role: 'After the outbreak of the crisis it is, however, clear that the silver issues became a vastly more seriously disturbing factor. The difficulty of the Treasury in maintaining the gold standard was vastly increased, and the suspension of gold payments became imminent' (1910, p. 179).

\section{The Panic of 1907}

The San Francisco earthquake of 17 April 1906 triggered a massive call on global gold reserves and a liquidity crunch in the US. From this, a recession commenced in June 1907. Security prices declined. On 16 October, a 'bear squeeze' speculation failed and prompted the insolvency of two brokerage firms. The next day, depositors began runs on trust companies and banks known to be associated with the speculators. The New York Clearing House Association refused to clear checks associated with the speculators' institutions. In this setting, J.P. Morgan moved to organize rescues of trust companies, banks, the New York Stock Exchange, the City of New York, and Moore and Schley, a brokerage firm.

Country banks learned from experience that, during a panic, withdrawing deposits from reserve city banks could be difficult. Thus, at the first 
news of bank runs in New York City, country banks rushed to withdraw deposits. This caused some reserve city banks to fall below the minimum reserve requirement set in the national or state banking charters. By 2 November, at least partial suspension of withdrawals had spread across the country, a fast contagion given that the first suspension by Knickerbocker, the prominent trust company, occurred on 22 October. In New York, the loss in loans and deposits was concentrated among the trust companies (Moen and Tallman, 1992).

By mid-November, the Treasury held only $\$ 5$ million in ready cash, effectively sidelining that institution from further influence over the course of events. A nation gasping for liquidity turned to other sources. Bank clearing houses issued their near-money certificates in rising numbers. Imports of gold began to arrive in significant volumes in November. The financial crisis ended in January when banks lifted their suspension of payments. The panic produced sharp economic contraction in 1908.

Trust companies played a central role in the crisis; Hansen (2014) details that losses during the panic were concentrated among these new institutions, having emerged as important intermediaries in the New York financial market in the late nineteenth century. Their assets grew 277 per cent in the ten years between 1898 and 1907 (as opposed to 97 per cent for national banks and 82 per cent for state banks). Trust companies were chartered by the state, faced less regulation than banks and had wider investment choices. They could also keep much lower legal reserves than banks. A combination of these factors encouraged the trust companies to invest in riskier assets (Moen and Tallman, 1992). Historian Vincent Carosso (1970) commented on the wide gamut of services that trust companies of the era provided:

Beginning in the 1890s, trust companies took on most of the functions of both commercial and private banks. They accepted deposits; made loans; participated extensively in reorganizing railroads and consolidating industrial corporations; acted as trustees, underwriters, and distributors of new securities; and served as depositories of stocks, bonds, and titles. (1970, p. 99)

In a brief period, the trust companies evolved rapidly; only in the early 1900s did New York State begin to regulate these new institutions, though the regulation was not as strict as it was for the national banks. Hansen (2014) argues that a lack of regulation does not explain the trust companies' centrality to the panic as much as rumour-mongering about a subset of these new institutions. Either way, information asymmetry associated with complexity stands as a prominent factor in this episode. The crisis illustrates how innovation can engender information asymmetry (considering how the innovation in question works and how it can play out under 
different scenarios) and can prevent the adoption of adequate risk management strategies.

An example of inadequate risk management at the system level was the absence of a lender of last resort for trust companies - a lender who could, in a crisis situation, restore confidence and contain panic withdrawals. The national banks in New York, in contrast, received aid from the New York Clearing House Association at the onset of the crisis. The effect of this difference was manifest, as runs on the national banks promptly stopped, while those on the trust companies continued until J.P. Morgan's intervention.

\section{Banking Crises of the Great Depression (1930-1933)}

The Great Depression commenced with the stock market crash of October 1929 and did not end until the US's mobilization for World War II in 1941. Contained within this long period of time was an intense crisis in the financial system that hastened and deepened the contraction of the entire economy.

From 1921 to 1929, the US economy expanded at annual real rates between 5 and 6 per cent. This was an inventive period in respect of the creation of new financial instruments and institutions: closed-end mutual funds; the expansion of banks' securities' affiliates; the establishment of publicly traded holding companies financed significantly with debt (Allegheny, Insull); and the appearance of building and loan associations, which were specialized real estate lending institutions.

Agriculture, however, did not share in the expansion. Farm prices had collapsed 40 per cent in the recession of 1920-21 and did not recover fully by 1929. Yet two major waves of deflation (1922 and 1929-33) meant that farm mortgage debt rose in real terms. The resulting crunch stressed farmers and their banks. Bank failures ensued from 1921 to 1929, with 70 per cent of them occurring in 12 farming states. With the onset of the Great Depression, loan losses skyrocketed and the wave of bank failures spread from farming to industrialized states.

Between the years 1930 and 1933, over 9000 banks failed - one-third of those in existence in 1929 - in four climactic episodes. One distinction of these crises is their localization in the interior of the US. Unlike earlier crises, disruptions in the New York money market were not a material factor. Scholars have offered a number of explanations for these crises, such as a decline in output, deflation, the gold standard regime and a global propagation of panic. As in any banking crisis, a number of factors in combination were at work. We discuss here one factor, which relates to the Innovation-Complexity hypothesis: US banks' large investment in German bonds in the years before the Great Depression. 
The US emerged as a major creditor nation as a result of World War I. The devastation of war prompted the European great powers to impose a cascade of indemnification claims on Germany and her allies. The US, in turn, looked to the allies to fulfil their debt obligations to the US. The fulfillment of these various claims depended critically on economic growth, which ironically was hampered by the Treaty of Versailles in 1919, which structured the quilt of obligations. In an effort to sustain economic recovery in Europe, the US Federal Reserve depressed interest rates in the US, in an effort to drive capital towards Europe. US banks participated in a major wave of foreign lending, much of it in German bonds, after economic stabilization in central Europe in 1924 - according to Eichengreen (1991), the banks' investment practices, however, were not prudent, as one can see in his description of the origination and distribution process:

In the 1920s, US banks working on commission, but lacking long-term relations with an established clientele of domestic bondholders, simply sought to maximize the volume of new bond flotations. Kickbacks allegedly induced government officials to contract for loans which their country had no prospect of repaying. Foreign bonds were aggressively marketed in the United States, sometimes with the aid of picture books that introduced investors to countries of which they were totally ignorant. Informational asymmetries and principalagent problems within issue houses and securities affiliates thus undermined the efficiency of the market. (1991, p. 152)

The US banks' innovative and aggressive practices of selling German bonds to bank customers and other banks (often smaller, Midwestern banks) meant that a large number of investors began to own assets of dubious quality and unknown risk. Risk assessment was particularly challenging for these investors because they lacked access to information about the original issuers of the bonds: the German municipalities and states. In 1931, with financial crisis deepening in Germany, many of the foreign borrowers started to default on their bonds. According to the historian Nelson (2012), these defaults led to a cascade of bank failures, which in turn caused fears about the stability of the whole banking system.

\section{Global Financial Crisis of 2007-2008}

The Global Financial Crisis, also known as the Subprime Crisis in the US, had its roots in the collapse of a debt-fuelled boom in residential real estate. As house prices began to fall in late 2006, speculators and risky borrowers started defaulting in rising numbers as the opportunity to sell houses at a profit began to fade. The impact of those defaults became apparent in November 2006, triggering failures and losses in the first half 
of 2007. A liquidity crunch in subprime mortgages began; investment demand for them dwindled, as did their market values. Mortgage loan originators lost money and/or went bankrupt. Rating agencies sharply downgraded the credit rating of mortgage-backed securities. Hedge funds that had specialized in those securities reported large losses and began to close.

In the autumn of 2007, banks reported large loan write-offs, closed special investment vehicles that specialized in subprime loans and cashiered their CEOs. Through the summer of 2008, rising mortgage defaults and deteriorating mortgage values put more pressure on financial institutions. In September 2008, the eye of the financial hurricane crashed ashore: investor confidence plummeted, credit market liquidity evaporated and institutions crumbled. Meanwhile, contagion through financial markets took the subprime crisis to a global level. By the end of 2008, the financial crisis had affected markets, industries and the assets of millions of investors and depositors.

This crisis is a particularly relevant case for demonstrating how innovation can lead to systemic risks. The innovations in question are shadow banks, such as investment banks, hedge funds, special-purpose vehicles, mortgage companies, and so on, and various kinds of securitizations and derivatives, such as collateralized debt obligations (CDOs) and credit default sswaps (CDSs). Ben Bernanke (2010), the then Chairman of the Federal Reserve, in his statement before the Financial Crisis Inquiry Commission in September 2010, highlighted the role of these innovations in the crisis.

The shadow banking institutions quickly grew in size and importance during the decades before the crisis. Because of inadequate regulatory oversight, they engaged in highly leveraged investments, for which they typically relied on short-term funds. This practice made them vulnerable to runs. As shadow banks' role in the financial system grew with time, they became significant sources of systemic risks. Also, the lack of regulation, and hence fewer reporting requirements than traditional banks, meant scarce information about the risk positions of many such institutions. Novel or complex structures and business models, coupled with inadequate information, made the systemic role of shadow banks opaque to the participants of the financial system. The problem with securitization was similar in some respects: a complex structure and a resultant opacity about their risk and systemic role. In addition, the originate-to-distribute model produced a chain of transactions, and investors at the end of the chain found themselves unable to obtain information about the underlying assets. Consequently, investors had to rely on the opinions of credit rating agencies. The rating agencies, however, failed to understand and 
communicate the systemic risks inherent in these instruments because of flawed modeling and conflicts of interest.

Another source of opacity was the complexity and diversity of derivatives, which prevented financial firms from assessing - and communicating to counterparties and regulators - their own exposure to derivatives. The exposure-related uncertainty was a major cause of the loss of confidence in other financial firms during the crisis.

During this time, the financial system became increasingly interconnected by the forces of globalization and technology. The high degree of interconnectedness increased the likelihood of a system-wide propagation of crisis. In addition, according to Andrew Haldane (2009), Chief Economist at the Bank of England, increasing homogeneity in the financial firms' balance sheets and risk management strategies in the years before the crisis made the whole system particularly susceptible to collapse, since trouble could flow with less resistance in a homogenous network.

Universal banks - large banks with commercial and investment banking as well as other financial services business - were behind much of the innovation and boom before the crisis. Because of their size and connectivity, they became critical nodes ('too big to fail') in the financial network. Moreover, the complexity and size of operation prevented these banks from devising adequate internal risk management strategies.

\section{CONCLUSION}

This chapter reviews six US financial crises in an exploration of the role played by system complexity. From this review, we induce and explore the hypothesis that innovation in financial instruments, institutions and markets heightens complexity and uncertainty, both of which figure in leading theories and empirical research on financial crises. We do not claim that innovation is the sole driver of crisis; rather, our study of historical precedent suggests that it complements other drivers.

Our review affirms the plausibility of the Innovation-Complexity hypothesis. The case studies show considerable variation in type of innovation, but in no instance was a prominent innovation factor absent. To summarize, the cases contain the innovations in financial instruments, institutions and markets seen in Table 1.1.

Even in the years prior to the most recent financial crisis, policymakers were aware of the association between innovation and systemic risks. Timothy Geithner (2006), then President of the New York Federal Reserve, outlined two challenges in the management of risks related to innovation. First, an innovation usually diffuses faster than the needed 
Table 1.1 Case studies - innovations in financial instruments, institutions and markets

\begin{tabular}{|c|c|}
\hline Crisis & Innovations \\
\hline Panic of 1792 & $\begin{array}{l}\text { Instrument: bonds issued by the US government } \\
\text { (rather than states) } \\
\text { - Institution: founding of the Bank of the United } \\
\text { States } \\
\text { - Market: establishment of trading market for US } \\
\text { bonds }\end{array}$ \\
\hline Panic of 1873 & $\begin{array}{l}\text { - Instrument: assets backing railroad bonds: land } \\
\text { granted by US government } \\
\text { - Institution: national banks } \\
\text { - Market: growth in market for secondary trading of } \\
\text { railroad bonds }\end{array}$ \\
\hline Panic of 1893 & $\begin{array}{l}\text { - Instrument: assets backing the US dollar and } \\
\text { potentially US bonds: silver and gold } \\
\text { Market: McKinley Tariff of } 1890 \text { and earlier } \\
\text { monetary legislation prompted major international } \\
\text { and domestic monetary flows }\end{array}$ \\
\hline Panic of 1907 & $\begin{array}{l}\text { - Instrument: consumer deposits and checking } \\
\text { - Institution: trust companies }\end{array}$ \\
\hline $\begin{array}{l}\text { Crash of } 1929 \text { and } \\
\text { associated bank runs }\end{array}$ & $\begin{array}{l}\text { - Instrument: German bonds, high-leverage } \\
\text { affordable home mortgage loans, private mortgage } \\
\text { insurance, two early forms of securitization } \\
\text { - Institution: Federal Reserve, which pursued } \\
\text { expansionary policy before crash and } \\
\text { contractionary policy 1929-1933. Closed-end } \\
\text { mutual funds, securities affiliates of banks, holding } \\
\text { companies (Allegheny, Insull), building and loan } \\
\text { associations }\end{array}$ \\
\hline $\begin{array}{l}\text { Global Financial Crisis } \\
\text { of } 2007-08\end{array}$ & $\begin{array}{l}\text { Instrument: securitizations of various kinds such as } \\
\text { collateralized mortgage obligations, credit default } \\
\text { swaps, etc. } \\
\text { - Institution: hedge funds, universal banks; new } \\
\text { expansionary policies pursued by the Federal } \\
\text { Reserve, Fannie Mae, Freddie Mac, etc. } \\
\text { Market: secondary trading in securitized } \\
\text { instruments }\end{array}$ \\
\hline
\end{tabular}


risk management systems and infrastructure can be put in place. This happens because it takes time for the regulators to get a sufficient grasp of the workings of a new instrument or institution. Second, innovations that take place in good economic times manifest their risk-generating properties only when the circumstances become adverse.

These case examples highlight the need for a greater understanding of innovation's system-wide role. Clearly, financial crises have many causes; innovation in financial instruments, institutions and markets is unlikely to be a sole explanation for these events. Yet, the prevalence over time of innovation as a factor in crises cannot be ignored. A complex systems perspective can guide us in our understanding by forcing us to consider the interdependencies, interactions and network structures in the financial system. We need a better view of the financial network's topology before we can begin to trace sources of systemic risks and the channels through which they can propagate. The recent crisis has spurred a number of studies (for example, Gai and Kapadia, 2010), in which researchers have applied advances in network science to develop analytical models of contagion and study interbank exposure and payment flows. While this is a development in the right direction, we propose that researchers also seek to understand how financial innovation affects the network topology through the creation of new nodes and links.

Joseph Schumpeter famously argued that innovation is associated with changes in the rules of competition among players in markets. Such rule changes require players to adapt behaviour. As economies grow and advance through waves of innovation, financial markets experience waves of stability and instability. In this chapter, we have attempted to add a perspective on what it is about complexity that may amplify the tendency towards panic - with a focus on financial innovation: in instruments, institutions and markets. We argue that innovations may worsen the negative consequences of systemic complexity.

\section{NOTES}

1. Nobel Prize-winning economist Herbert Simon once defined a complex system as: 'one made up of a large number of parts that interact in a non-simple way. In such systems, the whole is more than the sum of the parts, not in an ultimate, metaphysical sense, but in the important pragmatic sense that, given the properties of the parts and the laws of their interaction, it is not a trivial matter to infer the properties of the whole' (1962, p.468). The non-simple, or non-linear, interactions among the parts result in emergent behaviours at the system level that do not require central control. In complex adaptive systems, the parts can learn from and adapt to system-level emergent behaviours.

2. A financial instrument is a contract stipulating a future transfer of value between two parties (for example, stocks, bonds, loans, deposits, futures, and so on). Financial 
institutions primarily deal in financial instruments or provide financial services: such institutions include commercial banks, trust companies, investment banks, insurance companies, and so on. A financial market is a market where a certain financial instrument is bought and sold.

3. Several authors in Science (1999), 284 (5411) explained a number of attributes of complex systems: a high degree of structure (Goldenfeld and Kadanoff); evolution is sensitive to starting conditions and to small variations in conditions over time (this implies many possible paths along which evolution of the system might occur) (Whitesides and Ismagilov); the design or function of the system is difficult to understand and verify (Weng, Bhalla and Iyengar); components interact in multiple ways (Rind); and constant evolution over time (Arthur).

4. Taleb is known for introducing the idea of 'antifragile' systems, which 'thrive and grow when exposed to volatility, randomness, disorder, and stressors' (2012, p. 3). He has argued that excessive regulations intended to protect the financial system from small fluctuations are counterproductive, since such protection reduces the system's ability to cope with more severe disturbances.

\section{REFERENCES}

Allen, F. and D. Gale (2000), 'Financial Contagion', Journal of Political Economy, $108(1), 1-33$.

Arthur, W.B. (1999), 'Complexity and the Economy', Science, 284 (5411), 107-9.

Arthur, W.B. (2014), Complexity and the Economy, New York: OUP.

Beinhocker, E.D. (2007), The Origin of Wealth: Evolution, Complexity, and the Radical Remaking of Economics, London: Random House.

Bernanke, B.S. (2010), Causes of the Recent Financial and Economic Crisis, statement before the Financial Crisis Inquiry Commission, Washington, DC, 2 September.

Bookstaber, R. (2007), A Demon of Our Own Design: Markets, Hedge Funds, and the Perils of Financial Innovation, Hoboken, NJ: Wiley.

Caballero, R.J. and A. Simsek (2009), Complexity and Financial Panics, NBER Working Paper No. 14997, Cambridge, MA: NBER.

Calomiris, C.W. and G. Gorton (1991), 'The Origins of Banking Panics: Models, Facts, and Bank Regulation', in R.G. Hubbard (ed.), Financial Markets and Financial Crises, Chicago and London: University of Chicago Press, pp. 109-74.

Calomiris, C.W. and S.H. Haber (2014), Fragile by Design: The Political Origins of Banking Crises and Scarce Credit, Princeton, NJ: Princeton University Press.

Carlson, M. (2005), 'Causes of Bank Suspensions in the Panic of 1893', Explorations in Economic History, 42 (1), 56-80.

Carosso, V.P. (1970), Investment Banking in America: A History, Cambridge, MA: Harvard University Press.

Diamond, D.W. and P.H. Dybvig (1983), 'Bank Runs, Deposit Insurance, and Liquidity', The Journal of Political Economy, 91 (3), 401-19.

Eichengreen, B. (1991), 'Historical Research on International Lending and Debt', The Journal of Economic Perspectives, 5 (2), 149-69.

Friedman, M. and A.J. Schwartz [1963], A Monetary History of the United States, 1867-1960, Princeton, NJ: Princeton University Press, paperback edn, 1971.

Gai, P. and S. Kapadia (2010), 'Contagion in Financial Networks', Proceedings 
of the Royal Society A: Mathematical, Physical and Engineering Science, 466 (2120), 2401-23.

Geithner, T.F. (2006), Risk Management Challenges in the US Financial System, remarks made at the Global Association of Risk Professionals, 7th Annual Risk Management Convention and Exhibition, New York City, 28 February.

Goldenfeld, N. and L.P. Kadanoff (1999), 'Simple Lessons from Complexity', Science, 284 (5411), 87-89.

Haldane, A.G. (2009), Rethinking the Financial Network, speech delivered at the Financial Student Association, Amsterdam, 28 April.

Hansen, B.A. (2014), 'A Failure of Regulation? Reinterpreting the Panic of 1907', Business History Review, 88 (Autumn), 545-69.

Kindleberger, C.P. and R.Z. Aliber (2005), Manias, Panics and Crashes: A History of Financial Crisis, 5th edn, Houndmills: Palgrave Macmillan.

Mishkin, F.S. (1991), Asymmetric Information and Financial Crises: A Historical Perspective, NBER Working Paper No. 3400, Cambridge, MA: NBER.

Moen, J. and E.W. Tallman (1992), 'The Bank Panic of 1907: The Role of Trust Companies', The Journal of Economic History, 52 (3), 611-30.

Nelson, S.R. (2012), A Nation of Deadbeats: An Uncommon History of America's Financial Disasters, New York: Alfred A. Knopf and Toronto: Random House.

Noyes, A.D. (1909), Forty Years of American Finance: A Short Financial History of the Government and People of the United States since the Civil War, 1865-1907, New York: G.P. Putnam's Sons.

Perrow, C. (2009), Normal Accidents: Living with High-risk Technologies, with a new afterword and a new postscript by the author, updated edn, Princeton, NJ: Princeton University Press.

Rind, D. (1999), 'Complexity and Climate', Science, 284 (5411), 105-7.

Simon, H.A. (1962), 'The Architecture of Complexity', Proceedings of the American Philosophical Society, 106 (6), 467-82.

Sornette, D. (2003), 'Critical Market Crashes', Physics Reports, 378 (1), 1-98.

Sprague, O.M.W. (1910), History of Crises under the National Banking System, National Monetary Commission, 61st Congress, 2nd session, Senate document No. 538, Washington, DC: Government Printing Office.

Taleb, N.N. (2012), Antifragile: Things that Gain from Disorder, New York: Random House.

Weng, G., U.S. Bhalla and R. Iyengar (1999), 'Complexity in Biological Signalling Systems', Science, 284 (5411), 92-96.

Whitesides, G.M. and R.F. Ismagilov (1999), 'Complexity in Chemistry', Science, 284 (5411), 89-92.

Wicker, E. (2006), Banking Panics of the Gilded Age, New York: CUP. 